\title{
THE DYNAMICS ACCESS ON TOURISM GOVERNANCE IN WAKATOBI NATIONAL PARK
}

\author{
Abdul KODIR* \\ Universitas Negeri Malang, Faculty of Social Science, Sociology Department, Indonesia, e-mail: abdul.kodir.fs@um.ac.id \\ Risdawati AHMAD \\ Universitas Negeri Malang, Faculty of Social Science, Sociology Department, Indonesia, e-mail: risdawatiahmad@gmail.com \\ Nanda Harda Pratama MEIJI \\ Universitas Negeri Malang, Faculty of Social Science, Sociology Department, Indonesia, e-mail: nanda.harda.fis@um.ac.id
}

Citation: Kodir, A., Ahmad, R., \& Meiji, N.H.P. (2020). THE DYNAMICS ACCESS ON TOURISM GOVERNANCE IN WAKATOBI NATIONAL PARK. GeoJournal of Tourism and Geosites, 32(4), 1376-1383. https://doi.org/10.30892/gtg.32427-583

\begin{abstract}
This research aims to identification actors who compete towards access and how they get, control and maintain the access on tourism governance in Wakatobi National Park. The data collection is conducted through semi-structure interviewed some stakeholders and local communities who involved directly in tourism governance. Moreover, researchers also conducted participant observation in tour ism activities. This research showed that there were numerous actors who scrambling to gain, maintain and control access in tourism governance with different mechanisms which have been mediated by authority, capital, markets, technology, social identity and social relations. The Wakatobi National Park Official (BTNW) and Wakatobi Municipality were actors who dominated the access of tourism governance because both of act ors have a set of rules which could control the tourism activities. In addition, the private enterprises were actors who obtain and maintain the access in tourism activities because they have network with local government.
\end{abstract}

Key words: tourism, dynamics, governance, national park, access, wakatobi

$* * * * * *$

\section{INTRODUCTION}

Tourism is a sector that will continue to grow. Furthermore, this sector has become the flagship of almost entire countries in increasing economic growth both at the macro and micro scale (De Vita and Kyaw, 2017; Kodir, 2018; Lee et al., 2015; Ohlan, 2017; Deac et al., 2019). Moreover this sector also contributes to poverty reduction (Croes, 2014; Medina-Muñoz et al., 2016; Scheyvens, 2014; Spenceley and Meyer, 2012; Vanegas et al., 2015). However, in its development, it requires knowledge, thoughts, application of strengths, resources and rules, as well as coordination and cooperation among many actors. All of these concepts are the main features of governance (Bramwell, 2011).

Governance in the tourism sector is a challenging task because it involves a variety of actors (Carlos et al., 2013) whose interests clash with each other. Tourism is also considered as a fragmented industry of several interests such as large companies operating on a global scale and suppliers of micro, small and medium enterprises (Dredge, 2006). Even the government involvement in tourism management often makes it complicated because conflicting interests between each of these actors (Scott and Marzano, 2015). Although tourism management cannot be separated from competition, tourism governance has also been positioned as a potential aid for understanding, and possibly achieving, sustainable development in tourism (Brouder, 2015; Nunkoo, 2017; Ilies et al., 2017; Tătar et al., 2017).

Tourism governance is one of the issues that is significantly a concern for scholars in the world who have attention to development policies for tourism planning (Bichler, 2019; Jamal and Camargo, 2018; Joppe, 2018; Nunkoo, 2017; Valente et al., 2015; Valente and Bramwell, 2015; Yeh, 2018; Wahyuningtyas et al., 2020). This is considered important because researchers have tried to understand how countries can act best to mediate social, economic, political and environmental policy issues related to tourism. In some cases in various countries, tourism often becomes its own problems such as inequality in the management of tourism resources for local communities (Cole and Morgan, 2010; Kodir et al., 2019, 2020), income (Cingano, 2014; Alam and Paramati, 2016; Seligson and Kuznets, 2019) and access to the water (Cole, 2012, 2014, 2017; Cole and Browne, 2s015; Sinha et al., 2020). Tourism governance is a complex issue which sometimes cannot be brought closer to one approach, especially if tourism management is located in the national park area. This will be a conflict if the goal of tourism management is profit, but at the same time must make conservation efforts. But in its development, tourism and conservation are expected to run in a balanced way (Hewlett and Edwards, 2013; Jaafar et al., 2013, 2015) with model of natured-based tourism (Balmford et al., 2009; Fredman et al., 2012). Because after all the national park has the potential to be a tourist attraction as a regional development effort (Fredman and Wikström, 2018) and economic growth (Karanth et al., 2012; Mayer et al., 2010). The consequence is a shift in policy and the role of national parks which initially only as a function of maintaining biodiversity and conservation shifted into a tourism destination (Shultis and Way, 2006; Arnscheidt, 2008; Herman et al., 2019). This shift reflects the rise of liberalist politics in which nature conservation has become more instrumental and market oriented (Puhakka and Saarinen, 2013). Because the existence of tourism in the national park area is greater in terms of economic and political benefits than ecological sustainability (Almeida Cunha, 2010; Kaltenborn et al., 2011).

One of the complexities of tourism governance issues is one of which occurs in the Wakatobi National Park (WNP) area. WNP is one of the national parks in Indonesia whose area of management overlaps between the regional government (Wakatobi Municipality) and Wakatobi National Park Office (BTNW). Both of these actors have legal recognition. However, the complexity of management issues is not only in this aspect. Long years ago, the national park area was a customary community area where there were several tribes inhabiting this area, such as the Butonese, Cia-Cia, Bugis, Muna, and Bajau tribes. When the Wakatobi Islands were still under the authority of the Buton Sultanate, the sea and forest areas in the islands were managed by sara kadie or customary institutions that had the authority (Adimu et al., 2018). However, after the Wakatobi islands were designated a National Park conservation area, people's lives began to change, entire activities in the context of meeting the socio-economic needs and utilization of natural resources contained in the sea are limited by various

\footnotetext{
${ }^{*}$ Corresponding author
} 
regulations and regulations by the National Park Office (Elliott et al., 2001). In addition, the local government also did not involve the local community in making policies related to the management of Wakatobi National Park, especially related to tourism development.

The study of tourism in the Wakatobi National Park area has been carried out by several researchers. In its development, the management of tourism in WNP requires the right planner or manager to promote tourism that can directly protect protected or conservation areas (Von Heland and Clifton, 2015; Shomanova et al., 2017). One of them is with the development model of Marine Ecotourism. Some researchers try to review that Marine Ecotourism is a model of tourism development that can contribute to improving people's welfare (Syam et al., 2019; Tam, 2019) through involving stakeholders and NGOs (Soedjak, 2012; Dezsi et al., 2014). And also gives explicit recognition to the Bajau community who are consistently marginalized (Clifton, 2013). In addition, tourism development in the WNP region has transformed towards a green economy. This is demonstrated by the commitment of local governments to provide strategic direction, especially in budget planning to reduce greenhouse gas emissions and improve resource efficiency (Owners et al., 2019; Azhayev et al., 2020; Suleimenov et al., 2020). The diversity of tourism studies in the Wakakobi National Park area shows that this region is one of the interesting research objects. However, there is no study of tourism in the region trying to explain the complexity of actor relations in fighting over the Wakatobi region as a tourism destination. Therefore, this article will contribute to enriching the study of tourism development in the perspective of the dynamics of access and exclusion. As a study, this article adds a new perspective in tourism development planning which is currently oriented towards the development of tourism destinations that ignore political issues.

\section{METHOD AND RESEARCH SITE}

This research used qualitative research. The process of collecting primary data is conducted in several ways namely observation and interviews. The observations were carried out by conducting direct observations by visiting several tourism spots, resorts, the location of tourism development projects, and customary territories which are scattered in several groups of islands in Wakatobi National Park (Figure 1). While interviews were conducted with a number of participants including the Office of Tourism and Culture, the Office of Public Works, the Regional Planning and Development Agency (BAPPEDA), Indigenous Communities, Fishermen Groups, Resort Workers, Resort Owners, Local Enterprises, POKDARWIS, Political Elites, and NGOs.

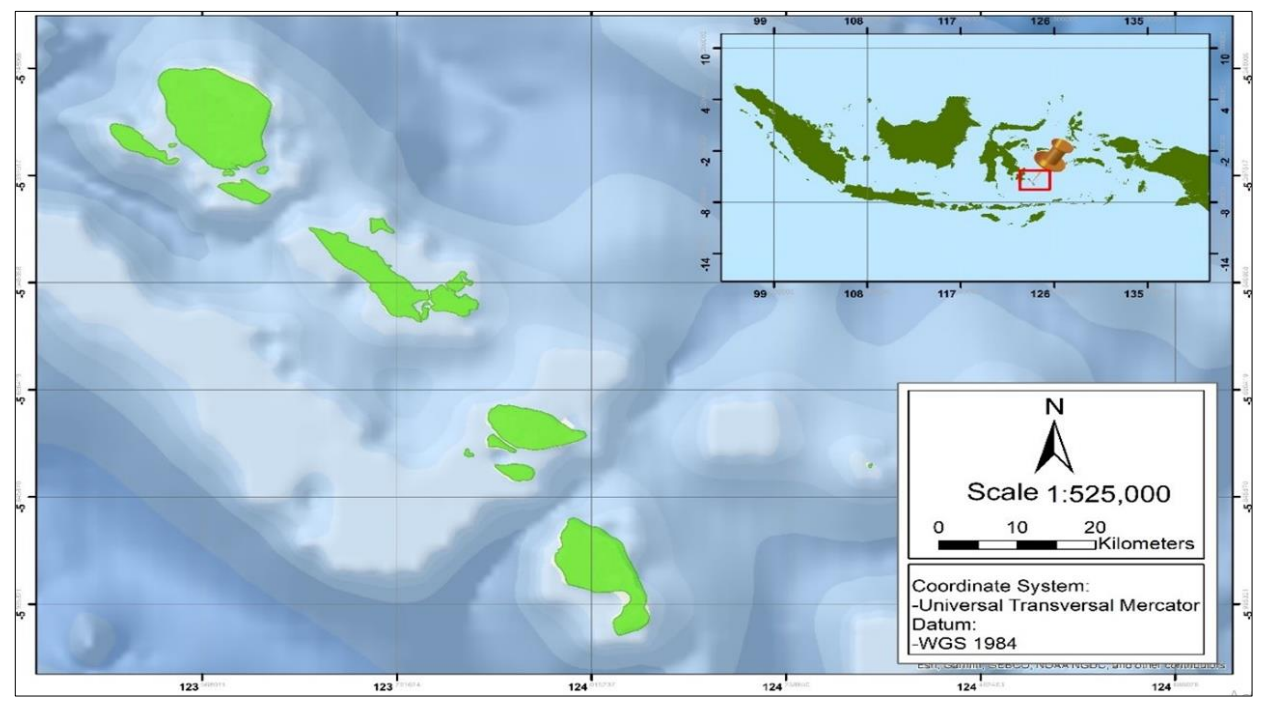

Figure 1. Research Location of Wakatobi National Park

Data analysis in this study uses thematic analysis. This analysis is carried out through several stages (Bryman, 2016). First, examine the results of the interview transcript of some key questions such as before being designated as a national park area, Does the manager of the National Park also have authority in tourism management ?; Who is involved in tourism governance ?; How do they get access to managing tourism? (legal or illegal?); Who is the party that benefits the most in tourism governance? Why?; Who is the most disadvantaged party in tourism management? Why? Then, we coded the results of the interview transcript from a few quotes and grouped the results of the interview based on the topics discussed namely about tourism management in the Wakatobi National Park and the community's response to the establishment of WNP as one of the Strategic National Tourism Area in Indonesia. And the last is interpreting findings from predetermined notions from the perspective of access theory.

\section{RESULT AND DISCUSSION}

\section{Identifying actors and mechanisms who competing for access in tourism governance}

The presence of the tourism industry in the Wakatobi National Park area (WNP) since 1996 has a significant influence on people's access to the resources that are the source of their economic income (Soedjak, 2012). Analysis of access to the use of natural resources in Wakatobi National Park (WNP) was carried out to identify how the actors access these resources. The dynamics of the conflict also gave a distinctive colour in opening access and rights to the use of natural resources in the WNP area (Khac, 2018; Von Heland and Clifton, 2015).

Access to tourism resources is contested by interested parties, both government, private, and the people who live in the area. This is because natural resources in the form of contested material objects can provide economic benefits for these parties. When peeled, WNP has a very abundant marine potential, the existence of fish in Wakatobi is estimated to reach 900 species, 750 coral reefs, 32 species of mangrove, 11 species of sea grass, two types of turtle, 12 species of cetacean, and 85 species of birds (Clifton et al., 2010; Dilwan and Astina, 2019; Junaid et al., 2019). This natural wealth causes the parties to fight over it to be managed because it has a high value of tourism commodities. In this arena of contestation, the parties involved have different interests and strengths (Hasan Eldin Adimu et al., 2017; Elliott et al., 2001). As a result, the ways or practices they use to access natural resources are also different. Based on the results of the identification of researchers, each actor has a different access mechanism in obtaining, controlling, and maintaining the flow of profits from tourism 
resources, and this means the actors have different roles in the struggle for access in WNP. As explained earlier, there are three main actors who have access to WNP tourism governance, namely the community, government, and private sector. Referring to Ribot and Peluso's (2003) access theory, the community is the actor who has the role of maintaining access, the government has the function of controlling access, and the private sector has the role of obtaining and maintaining access.

\section{Local Society and Indigenous People: The actors who are maintaining the access}

Before being designated as a National Park area in 1996, people living in the area claimed that access to the use of natural resources and the environment was managed from generation to generation based on customary law (Baskara et al., 2011; Simonin, 2015). Both local communities and indigenous people in the Wakatobi National Park use natural resources to meet their daily needs by catching fish in the surrounding waters. However, after being designated as a conservation area, the territorial waters are protected by the zoning system. Fishers are only allowed to carry out activities in the local use zone. In contrast, the core zone and maritime protection zone are prohibited zones (Firmansyah et al., 2017) because these two zones are only intended to protect flora and fauna, unique ecosystems, biodiversity, and other conservation activities. This causes a decrease in the amount of catch and economic income of the community because fishing locations are increasingly narrow (Sharma and Rajagopalan, 2013). Communities as villagers whose territories are within conservation areas do indeed have limited access to natural resources due to conservation regulations (Clifton, 2013). However, they cannot be broken just like that that they still have the right and ability to exploit the potential that exists at the village scale, especially potential associated with tourism jobs that are in line with eco-tourism destinations. In utilizing the potential of resources, the rights and abilities of the community are guaranteed by the Village Law No. 6 of 2014. Legally regulated that entire elements of the village have the authority to increase basic needs through the utilization of the potential of natural resources and the environment on a village scale (Antlöv et al., 2016).

However, in this study, researchers distinguish between rights and abilities based on the perspective of Ribot and Peluso (2009). According to them, rights and abilities lie in the difference between access and property. Access is more directed to ability, whereas property means ownership is rights. Ability is the same as power; moreover, the ability can be understood as a bundle of power and a web of power that gives space to actors to gain access and maintain access to resources, in this context is the community in the region WNP. When access is a set of powers that enable people to obtain and retain access, communities in the Wakatobi National Park form a power bundle of power to be able to obtain and maintain access to resource management (Ribot and Peluso, 2009). The power association is in the form of an indigenous community which is used as a container for the struggle for access in maintaining resources in its territory. Through this community, they can utilize resources and be involved in their management systems. In this context, indigenous communities that seek to maintain access to natural resources are fishing communities found on the four main islands in the Wakatobi National Park (WNP), namely Wangi-Wangi, Kaledupa, Tomia and Binongko Islands. Communities on these four islands form a common bond or association named after their respective regional names, including; Komanangi (Wangi-Wangi Fishing Community) in Wangi-Wangi, Forkani (Kaloudupa Forum Toudani) in Kaledupa, Komunto (Tomia Fishing Community) in Tomia, and Foneb (Binongko Fishermen Forum) in Binongko. In general, these four communities were established to be able to maintain access to natural resources in their villages that are part of the WNP area (Soedjak, 2012).

The four communities above have a uniform mission, which is to protect the sea from damage because it is undeniable that the sea is still one of their sources of livelihood until now. The presence of these four indigenous communities is a form of response to the decline in the number of fish and sea conditions that are increasingly threatened due to tourism activities. The role of these four communities is to understand and voice the wishes, needs, and opinions of the local community, and to provide environmental education that the sea is their main source of livelihood because sea damage will also impact on the community. In responding to environmental issues, Komunto then designed several programs to prevent damage and preserve fisheries and marine resources, including creating a fish bank program. Thanks to his efforts, the sea has been successfully conserved and is producing far more abundant fish. In addition to being involved in environmental protection, Komunto also initiated the mapping of indigenous areas in Tomia. The mapping plan was carried out through a Focus Group Discussion (FGD) and field survey aimed at determining the coordinates of the conventional territorial boundaries contained on land and sea.

In maintaining access to natural resources in WNP, Komunto refers to the prevailing customary law. This is because long before it was established as a National Park, this law was implemented by the Wakatobi community (Burke et al., 2011). The management of the sea and the natural resources contained therein have always been managed based on customary law (de Alessi, 2014). Customary marine management is known as Adati Pasi or customary coral. The symbol is huma or sea houses. Huma serves as a place to manage the surrounding sea. Like adjusting the capture area based on the use of fishing gear. Fishing using certain tools in places that should not be subject to sanctions. In order for this indigenous community to have the strength of access to resource management in their village, collaboration, and support from other parties who have power in the WNP are needed. In this case, the participation of traditional institutions to protect the sea received a good response from the National Park as the manager by providing support in terms of environmental care. Besides, BTNW and indigenous communities also often collaborate when there are cultural-based activities at WNP. Thus, it can be said that the presence of an indigenous community and the existence of support from the National Park is part of the ability of the community that forms a bundle of power to maintain access to the resources in their area.

Even though they have the support, the access that is gained by the community is not proportional to the power that BTNW has in governing tourism (Armitage and Tam, 2007). The government and the National Park as the manager of tourism in Wakatobi, can be said to have great power in every decision making. While local groups or communities only strengthen this position. Research conducted by Soedjak (2012) states that tourism planning carried out by managers does not fully involve stakeholders. For this reason, the community represented in this case by the adat community is trying to maintain access to continue to contribute to the management of the resources in their area.

\section{Wakatobi National Park Official and Wakatobi Municipality: The actors who are controlling the access}

The governance of the Wakatobi National Park tourism area experiences a dualism of authority, between the Wakatobi Municipality and the Wakatobi National Park Official. Both of these state institutions claim mutual rights over the use of natural resources in Wakatobi (Sopari et al., 2014). This is because after being designated as a National Park area based on Minister of Forestry Decree No. 393 / KPTS-VI / 1996 dated 30 July 1996, this area was then designated as a new district, which is a division of Buton District based on Law No. 29 of 2003. After being established as a district, the local government established the Wakatobi Tourism Office in charge of developing and managing tourism assets in the region. Whereas, previously, the National Park was the first ruler and positioned himself as the party entitled to the resources in Wakatobi. As a result of these two institutions, namely BTNW (Wakatobi National Park Office) and Wakatobi Municipality have been competiting each other to access resources in Wakatobi.

In general, there are eight types of biodiversity are controlled by BTNW and Wakatobi Municipality which both of them have similiar way to control. The eight resources are presented in Table 1 below: 
The Dynamics Access on Tourism Governance in Wakatobi National Park

Table 1. Biodiversity that managed by the Wakatobi National Park Office and the Wakatobi Municipality (Source: Interviews, 2019)

\begin{tabular}{|c|l|l|l|}
\hline No & \multicolumn{1}{|c|}{ Type of Biodiversity } & Governed by Wakatobi National Park Official & \multicolumn{1}{|c|}{ Governed by Wakatobi Manucipality } \\
\hline 1 & Coral reefs & $\begin{array}{l}\text { Monitoring, Area Security Patrol, Counseling / } \\
\text { Socialization, Tourism }\end{array}$ & $\begin{array}{l}\text { Monitoring, Area Security Patrol, Counseling } \\
\text { / Socialization, Tourism }\end{array}$ \\
\hline 2 & Seagrass & $\begin{array}{l}\text { Monitoring, Area Security Patrol, Counseling / } \\
\text { Socialization }\end{array}$ & $\begin{array}{l}\text { Monitoring, Area Security Patrol, Counseling } \\
\text { / Socialization }\end{array}$ \\
\hline 3 & Mangrove & $\begin{array}{l}\text { Monitoring, Area Security Patrol, Counseling / } \\
\text { Socialization, Tourism }\end{array}$ & $\begin{array}{l}\text { Monitoring, Area Security Patrol, Counseling } \\
\text { / Socialization, Tourism }\end{array}$ \\
\hline 4 & Seabirds & $\begin{array}{l}\text { Monitoring, Area Security Patrol, Counseling / } \\
\text { Socialization }\end{array}$ & Area Security Patrol \\
\hline 5 & $\begin{array}{l}\text { Cetaceans (Marine Mammals / Dolphins, } \\
\text { Whales) }\end{array}$ & $\begin{array}{l}\text { Monitoring, Area Security Patrol, Counseling / } \\
\text { Socialization }\end{array}$ & Area Security Patrol \\
\hline 6 & Turtle & $\begin{array}{l}\text { Monitoring, Area Security Patrol, Counseling / } \\
\text { Socialization }\end{array}$ & $\begin{array}{l}\text { Monitoring, Area Security Patrol, Counseling } \\
\text { / Socialization }\end{array}$ \\
\hline 7 & SPAGs (Fish Spawning Sites) & $\begin{array}{l}\text { Monitoring, Area Security Patrol, Counseling / } \\
\text { Socialization }\end{array}$ & Area Security Patrol \\
\hline 8 & Economical important fish & $\begin{array}{l}\text { Monitoring, Area Security Patrol, Counseling / } \\
\text { Socialization }\end{array}$ & $\begin{array}{l}\text { Area Security Patrol, Capture Fisheries } \\
\text { Permit }\end{array}$ \\
\hline
\end{tabular}

Based on the table above shows that both BTNW and the Wakatobi Municipality have the authority to oversee natural resources in the WNP area to protect these resources. This causes the actors attempt to control what activities are appropriate or inappropriate carried out in the area by referring to the principles of conservation. To exercise its authority, access controllers need the power to keep access to certain resources open (Berry, 2002). Here it is clear that the management or actors mentioned above are in a dominant position holding control over resources. Certainly, the political economy aspects of these actors become clear when the actors divide social authority into access control. Access control is the ability to mediate the access of others, for that control refers to checking and direction of action, function, or power of directing and regulating free action (Rangan, 1997). At first, the Wakatobi people made a living as fishermen, but when the area was designated as a National Park, the living conditions changed drastically (Carnegie, 2014; Stacey et al., 2017). People are prohibited from fishing at zoning points because it is feared that it will damage the living natural resources and disrupt tourist activities. Instead, the manager deliberately strived for people to switch jobs to the tourism sector. This effort was made to support the notion of ecotourism carried by the Wakatobi municipality and BTNW. One of the steps taken to realize ecotourism-based tourism in the WNP Area, both the National Park and the Tourism Office, is to form a tourism village and Tourism Awareness Group (Pokdarwis) (Nugroho et al., 2018; Owners et al., 2019).

There are a large number of assisted villages covered by Wakatobi National Park Official (BTNW). However, many have failed because of the lack of consistency of assistance (Junaid et al., 2019). The government only came to assist without any sustainability of the program. Of the large number of villages in Wakatobi, the National Park has only succeeded in forming two tourist villages, namely Makmur Village and Wali Village, in Binongko District. In Makmur Village, BTNW is focusing its development on improving the community's economic efforts through a marine product processing program, making shredded fish and assisting fishers in the provision of fishing gear. While in Wali Village, BTNW is more focused on turtle conservation and souvenir development programs. Similar to BTNW, the government also did the same thing, namely forming a Tourism Awareness Group (Pokdarwis). The formation of Pokdarwis did not have a significant influence on the development of tourism in Wakatobi (Junaid et al., 2019), because this institution only focused on how to build public awareness of tourism activities, not on how to manage tourism.

The shifting of people's livelihoods from previously fishers to tourism workers, as explained above, is enough to prove how much access control these two actors have. In this context, Ribot and Peluso (2009) in the lens of political economy analysis will help understand access controls leading to the examination and supervision of actions, which serve as the power to control and regulate the benefits of the desired resources. Based on the results of the interview, a statement was obtained from key informants that in controlling access, the government not only has the right as a supervisor and controller of access but also benefits economically from the benefits of tourism resources in the NWP area. This is following the argument of Ribot and Peluso (2009), who say that at the same time, there are meanings and values of resources which always contest between who controls access to resources and who maintains access to resources.

In addition to controlling the community in the technical relations of work to resources, the government also does the same thing to the private sector. The Wakatobi Municipality and BTNK have the right to grant tourism business licenses to the public or private parties. The latter wish to establish businesses within the area. Business licenses through the Regional Government are known as TDUPar (Tourism Business Registration Certificate). Business founders will be charged a registration fee and other costs according to the stipulated regulations. Responding to this regulation, the local community expressed their disapproval, especially the non-governmental organization that had just set up a business. The Chairman of the Wakatobi Tourism Forum believes that the right course of action should be done first is to strengthen the group. When strengthening and increasing the capacity of members has been implemented. The next step that will be taken is marketing. After all, stages are carried out, and the non-governmental organizations are independent, the government has the right to impose business costs on them. In contrast to the legalization of tourism business licenses managed by BTNW. According to the community, the business registration fee set by BTNW is more affordable than the Regional Government. In addition, the licensing process lasted only one day. After obtaining the permit, BTNW provides a guidance form for the permit holders to function if there is a problem.

The policy made by the Regional Government and Wakatobi National Park proves that, in the end, the control over access itse lf can be converted by the controlling actors into economic benefits for them. According to Marx's notion (Ribot and Peluso, 2009) about the relationship between investors and labor in the context of controlling access to tourism resources, that the relationship between actors who have the capital and those who work with other people's capital or means of production is parallel with the relationship between actors who control the access of others and those who must maintain their access. In the case of acce ss control by the government is in the relationship between two groups of actors sharing the benefits that are negotiated. To maintain access, subordinate actors often transfer several benefits to those who control access. They spend resources to foster re lationships or transfer benefits to those who control access to get their benefits. This kind of analysis can exceed class analysis because the control and maintenance strands can be in the same person or shared between actors who work together or compete. Likewise, the community in the area with WNP managers can work together to keep the area functioning as it should, by collecting data on every business permit and tourism activity as well as coaching by the manager to the community to protect the area in the WNP area. 


\section{Private Enterprises: The actors who gain and maintaining the access}

The private parties who have involvement in various types of businesses in the tourism business in the Wakatobi National Park area needs to be conducted. According to Masoed (1994), there are a variety of interested actors, including: first, there are actors called intermediaries in the tourism business, actors of this type such as tour operators and travel agents in general but their work power is limited to a small scale and not bound in a network of global tourism companies and tourist associations or associations. This type of actor is free to determine the product or tour package according to customer demand from the product offered to the market. Second, corporate or individual actors who invest venture capital in the tourism sector, these types of actors gain access through legal and state-protected legal channels.

Based on the results of the research, it is known that several corporations are included as the second type of actors, including Patuno Resort Wakatobi, Wakatobi Bajo Resort, Mawadah Dive Center, and Operation Wallacea. Patuno Resort Wakatobi was established at the end of 2009 and is located on Wangi-Wangi Island. One of the sahan owners of Patuno Resort is the family of the Wakatobi Regent. Patuno offers diving packages and has certified dive masters and marine biologists. In addition, Patuno also serves snorkeling trips, dolphin watching, and cultural island tours. Patuno resort is also known to monopolize the government agenda. Some important regional activities are often carried out at this resort, such as the holding of the International Seminar on Biosphere Reserves, the General Assembling of Local Government Networks on CTI Country, and the Focal Group Discussion (FGD) of the Indonesian Sail Tourism Association.

The next actor who also has rights to a business permit in WNP is Wakatobi Dive Resort (WDR) (Dilwan and Astina, 2019). Wakatobi Dive Resort (WDR) is owned by Lorenz, which has been operating since 1999 or four years before Wakatobi was established as a district. The company's operating permit is obtained through a Foreign Investment (PMA) permit, which is administered directly to the central government in Jakarta. Whereas other operational licenses were obtained through the Buton municipality. After the PMA was published, WDR built airports, resorts, and prepared human resources. The business license is valid for 30 years and can be refined again. When Wakatobi became a municipality, the business license remained valid. The main problems facing WDR are resort land leasing, airport land compensation, privatization, and beach reclamation. WDR acquires land by renting community property. The leasing mechanism is a new problem because the existing land system is communal ownership, not private ownership, which causes horizontal conflicts. Communal ownership is formed through inheritance of land which is carried from generation to generation from one generation to the next. In addition, land disputes also occur between WDR and the people on Tomia Island. WDR itself is known to have a private airport with flight routes from Bali to Tomia. This airport was built on land owned by 104 families with an area of \pm 10 ha. The polemic arose because the community considered that the compensation given by WDR had not yet been completed.

Furthermore, Mawadah Dive Center, which is a dive center on Wangi-Wangi Island. Mawadah is an acronym for "Magnet Wakatobi Dahsyat," which means great Wakatobi magnets. The center offers diving and snorkeling trips that are guided by certified divers, as well as diving equipment rentals. In addition, they also offer dolphin watching tours and tours to cultural villages. The last private actor who has tourism business licensing rights in WNP is Operation Wallacea. Operation Wallacea is a UK-based research volunteer who operates biological management and conservation research programs in eleven countries around the world (Martin et al., 2012; Ullah et al., 2017). In Wakatobi National Park, Operation Wallacea is based on Hoga Island and has operated a diving and marine research center since 1996. Operation Wallacea organizes and operates voluntary research trips for students undertaking undergraduate and master field study projects. Every year Operation Wallacea sends up to 300 students mostly from England to Hoga Island to conduct research, where students pay a fee. These projects are mostly designed to meet the long-term conservation objectives of the National Park. The third type of actor according to (Masoed, 1994), is the local villagers who are native peoples of the region who are running a tourism business, most of whom run businesses in the field of tourism services and only have limited financial or means, such as travel agents, services homestay, tour boat, etc.

After mapping the private parties who are actors in the tourism business in WNP, it can be said that these actors are very complex so that not entire actors found are used as research subjects. However, there are more or fewer patterns that have similar entity levels in gaining access to the benefits of tourism resources in the WNP area. However, business entities, most of the actors participating in taking advantage of the resources available in the Wakatobi National Park area, are a form of opportunity related to the natural potential that is utilized for tourism that can generate sustainable financial benefits. Actors who have the opportunity to utilize tourism resources in the WNP area must have a business license as specified. Thus, ownership of the permit is a form of the ability of the actors who want to gain access to tourism resources in the WNP area. According to Ribot and Peluso (2009) that in gaining access, there is the ability to benefit from something, including material objects, individuals, institutions, and symbols. In this access formulation, it provides wider space for social relations that can make people able to benefit from resources without focusing on property, but rather on the ability to obtain business licenses (Sikor and Lund, 2009).

Indeed, when actors who have gained access to benefits to tourism resources maintain their access through actors who have control over resources (Rubinson, 2005; Kodir, 2019), such as the government. Then after the actor gets the desired access, he must follow the rules, pay rent tax, establish communication with the government, approve policies made by the government, provide excise, and so on. This is done so that the actor in control (the government) does not cancel or revoke his access permit for resources so that actors who obtain access can use and utilize tourism resources as a form of economic surplus benefits. The strategy undertaken to coordinate the maintenance of access is to form tourism associations such as ASITA (Association of Indonesian Travel Companies). This is in accordance with what is said (Ribot and Peluso, 2009) regarding the formation of a bandle of power to maintain access.

\section{The actors who have dominated access in controlling natural resources in Wakatobi National Park}

Power relations between actors can occur in the form of conflict or competition, cooperation (negotiation), and resistance in obtaining benefits from natural resources (Aagesen et al., 2000; Ribot and Peluso, 2009). The form of relations in the way of conflict or competition will undoubtedly be won by actors who have a bundle of power that is greater than other actors. Actors who have more ability can influence other actors in controlling, utilizing, and maintaining resources (Febryano et al., 2015; Priyatna et al., 2015). Based on the analysis above, three actors interact with each other and have access to tourism resources in the Wakatobi National Park, namely indigenous peoples or actors who maintain access, Wakatobi National Park, and Local Government or actors who control access, and private or actors who obtain and secure access.

The governance of WNP tourism resources shows the existence of very complex power relations formation. This is because each actor has different interests in accessing resources. Before being designated as a National Park, indigenous peoples in Wakatobi Municipality. The dweller worked as fishermen to meet their economic needs. However, when tourism began to enter and Wakatobi was designated a National Park, people's lives slowly changed. Zoning systems restrict fishing areas for tourism purposes. This situation causes the community to lose fishing locations, so they have to switch jobs to other sectors. In addition, in 2003, Wakatobi was established as a new district by the local government based on Law No. 29 of 2003. The presence of the National Park and the formation of new districts has made the governance of tourism resources in Wakatobi increasingly complex. Both the BTNK and the Wakatobi municipality are state representatives who provide legitimacy for the presence of tourism in Wakatobi National Park. As actors who have the right to tourism licensing, these two actors give 
the maximum opportunity for the private sector to participate in the contestation of the management and utilization of natural resources in WNP. If analyzed from the powers held, the National Park and Local Government are the dominant actors who have the most significant access to tourism resources. This is supported by the state, which sets various systems and regulations to strengthen the rights of the actors in power so that these two actors can control the access that is owned by other actors. The following are the legal bases governing the management of Wakatobi National Park owned by the Wakatoby National Park Official and the Wakatobi Municipality (Table 2):

Table 2. Results of Analysis of Regulations in Wakatobi National Park and Wakatobi Municipality

\begin{tabular}{|c|c|c|}
\hline No & ctors & egal Basis \\
\hline 1 & $\begin{array}{ll}\text { Wakatobi National Park Official: } \\
-\quad & \text { SBTU (Sub Division of } \\
& \text { Administration in Baubau) } \\
- & \text { SPTNW I (Wangi-Wangi Region } \\
& \text { National Park Management Section) } \\
- & \text { SPTNW II (Kaledupa } \text { Region National } \\
& \text { Park Management Section) } \\
- & \text { SPTNW III (Tomia Region National } \\
& \text { Park Management Section) }\end{array}$ & $\begin{array}{l}\text { - Law No. } 5 \text { of } 1990 \text { concerning Conservation of Biological Natural Resources and their } \\
\text { Ecosystems } \\
\text { - Government Regulation No. } 36 \text { of } 2010 \text { and the Minister of Forestry Regulation No. } 48 \text { of } 2010 \\
\text { concerning Exploitation of Nature Tourism in Wildlife Reserves, National Parks, Grand Forest } \\
\text { Parks, and Nature Tourism Parks } \\
\text { - Director-General of Forest Protection and Nature Conservation (PHKA) Regulation No. P. } 7 \text { / IV- } \\
\text { Set / } 2011 \text { concerning procedures for entering the Nature Reserve Area, Nature Conservation Area } \\
\text { and Buru Park } \\
\text { - Government Regulation No. } 59 \text { of } 1998 \text { concerning tariffs on the types of PNBP that apply to the } \\
\text { Ministry of Forestry and Estate Crops } \\
\text { - Monitoring Standard Operating Procedure (SOP) } 8 \text { Important Resources }\end{array}$ \\
\hline 2 & $\begin{array}{l}\text { Wakatobi Municipality: } \\
\text { - Regional Development Planning, } \\
\text { Investment, Research, and Development } \\
\text { Agency } \\
\text { - Department of Marine and Fishery } \\
\text { - Environmental Agency } \\
\text { - Department of Culture and Tourism } \\
\text { - Department of Agriculture, Forestry, } \\
\text { Plantation and Animal Husbandry } \\
\text { - Department of Spatial Planning, Cleanliness, } \\
\text { Parks, Cemeteries and Fire Department }\end{array}$ & $\begin{array}{l}\text { - Law No. } 27 \text { of } 2007 \text { concerning Management of Coastal Resources and Small Islands } \\
\text { - Law No. } 45 \text { of } 2009 \text { concerning Amendment to Law No. } 31 \text { of } 2004 \text { concerning Fisheries } \\
\text { - Law No. } 32 \text { of } 2009 \text { regarding Environmental Protection and Management (PPLH) } \\
\text { - Wakatobi Municipality Regulation No. } 5 \text { of } 2009 \text { concerning Use of Fishing Tools and / or Tools } \\
\text { for Taking Marine Products in the Wakatobi Municipality Water Areas } \\
\text { - Wakatobi Municipality Regulation No. } 5 \text { of } 2009 \text { concerning Use of Fishing Tools and / or Tools } \\
\text { for Taking Marine Products in the Wakatobi Municipality Water Areas } \\
\text { - Wakatobi District Regulation No. } 18 \text { of } 2013 \text { concerning Fishery Business Licenses } \\
\text { - Wakatobi Municipality Regulation No. } 19 \text { of } 2006 \text { concerning Research Permit Retribution and } \\
\text { Granting Receipt of Notification of Empowerment of Social Organizations, NGOs and Foundations } \\
\text { - Wakatobi District Regulation No. } 15 \text { of } 2013 \text { concerning Recreation and Tourism Sports Levies }\end{array}$ \\
\hline
\end{tabular}

Those policies are a legal umbrella to protect the rights of the actors in power in the management of tourism resources in WN P. Any party that will establish a tourism business in WNP must go through the permission of these two institutions. In addition, a s the owner of a permit, both the public and private sectors must comply with formal regulations that have been established and mutually agreed upon. This proves that BTNW and the Wakatobi District Government can control the access of other actors. As explained earlier, the Wakatobi National Park and District Government control community access to the sea that is their source of livelihood through the zoning system. The two actors also led the community to work in the tourism sector by establishing a tourism village, the aim being to support tourism activities in the region. Meanwhile, the control of BTNW and the Wakatobi Municipality over the private sector is by providing operational licenses for tourism businesses that are run within a certain time.

\section{CONCLUSION}

The determination of the Wakatobi National Park as one of the locations of KSPN is because WNP has the advantage of biodiversity and coral reef ecosystem which attracts domestic and foreign tourists. As a potential tourism location, the existence of tourism encourages several actors to be involved in tourism governance in the region. However, in its governance, several actors involved in tourism governance compete with each other to compete for access with a variety of mechanisms. Indeed, this is mediated by se veral aspects such as authority, capital, markets, technology, social identity and social relations.

This research has identified several actors involved in tourism governance in the national park area including the Wakatobi municipality, national parks, foreign businessmen or local elites, local communities, and indigenous peoples. With a variety of actors involved in the management of tourism in the national park area shows the formation of complex power relations. In this conte xt, the Wakatobi municipality and BTNW are actors who dominate tourism management because these two actors are supported by a set of authorities and rules. Furthermore, those who also benefit from the utilization of tourism management are foreign entrepreneu rs and local elites. They have the freedom to obtain and maintain access not only from the strength of the capital and market they have, but are supported by relations with the local government that makes it easy for them to obtain permits for tourism management. Meanwhile, those who can only maintain access are local people, they only become a small part in tourism management. And even from their limited access to use their livelihoods due to the restrictions on their area of fishing because of the zoning system established by the national park and some privatization of space for tourism. This research has conveyed the complexity of governing tourism in the Wakatobi National Park area. However, this research is limited to explanations relating to policies and contestation of interests in touris $\mathrm{m}$ governance which, in the end, local communities or indigenous peoples become disadvantaged actors due to unfair tourism governance.

As a recommendation, further research is expected to be able to explain how local communities, especially those not involved in tourism activities such as fishermen or Bajau community, adapt to social changes and ecological vulnerability caused by tourism development massiveness due to the establishment of the Wakatobi National Park as one of the National Tourism Strategic A reas.

\section{REFERENCES}

Aagesen, D., Bryant, R.L., \& Bailey, S. (2000). Third World Political Ecology. Environmental History, 5(1), 124-125.

Adimu, H E, Boer, M., Yulianda, F., \& Damar, A. (2018). Review Management Policy Marine Conservation Area of Wakatobi National Park. IOP Conference Series: Earth and Environmental Science, 176. https://doi.org/10.1088/1755-1315/176/1/012035

Adimu, Hasan Eldin, Boer, M., Yulianda, F., \& Damar, A. (2017). The role of stakeholders in marine conservation areas in Wakatobi National Park, Indonesia. AACL Bioflux, 10(6), 1483-1491.

Alam S., \& Paramati, S.R. (2016). The impact of tourism on income inequality in developing economies: Does Kuznets curve hypothesis exist? Annals of Tourism Research, 61, 111-126. https://doi.org/10.1016/j. annals.2016.09.008

Almeida Cunha, A. (2010). Negative effects of tourism in a Brazilian Atlantic forest National Park. Journal for Nature Conservation, 18(4), 291-295. https://doi.org/10.1016/j.annals.2016.09.008 
Antlöv, H., Wetterberg, A., \& Dharmawan, L. (2016). Village Governance, Community Life, and the 2014 Village Law in Indonesia. Bulletin of Indonesian Alam Economic Studies, 52(2), 161-183. https://doi.org/10.1080/00074918.2015.1129047

Armitage, D., \& Tam, C.L. (2007). A political ecology of sustainable livelihoods in coastal Sulawesi, Indonesia. Canadian Journal of Development Studies, 28(01), 39-57. https://doi.org/10.1080/02255189.2007.9669187

Arnscheidt, J. (2008). "Debating" Nature Conservation: Policy, Law and Practice in Indonesia : A Discourse Analysis of History and Present. Debating Nature Conservation: Policy, Law and Practice in Indonesia : A Discourse Analysis of History and Present. https://doi.org/10.5117/9789087280628

Azhayev G., Esimova D., Sonko S.M., Safarov R., Shomanova Zh., \& Sambou A. (2020). Geoecological environmental evaluation of Pavlodar region of the Republic of Kazakhstan as a factor of perspectives for touristic activity. GeoJournal of Tourism and Geosites, 28(1), 104-113. https://doi.org/10.30892/gtg.28108-455

Balmford, A., Beresford, J., Green, J., Naidoo, R., Walpole, M., \& Manica, A. (2009). A global perspective on trends in nature-based tourism. PLoS Biology, 7(6), 1-6. https://doi.org/10.1371/journal.pbio.1000144

Baskara, B., Astuti, O., \& Kunci, K. (2011). The "Pamali" of Wakatobi Bajo and Its Role for Marine Conservation. Journal of Indonesia Coral Reefs.

Berry, S. (2002). Debating the land question in Africa. Comparative Studies in Society and History, 44(4), 638-668. https://doi.org/10.1017/S0010417502000312

Bichler, B.F. (2019). Designing tourism governance: The role of local residents. Journal of Destination Marketing and Management, 100389. https://doi.org/10.1016/j.jdmm.2019.100389

Bramwell, B. (2011). Governance, the state and sustainable tourism: A political economy approach. Journal of Sustainable Tourism, 4(5), 459-477. https://doi.org/10.1080/09669582.2011.576765

Brouder, P. (2015). Tourism governance: critical perspectives on governance and sustainability. Anatolia, 26(3), 489-492. https://doi.org/10.1080/13032917.2014.986491

Bryman, A. (2016). Social Research Methods. 5th ed, Oxford, University Press.

Burke, L., Reytar, K., Spalding, M., \& Perry, A. (2011). Reefs at Risk: Revisted. World Resources Institute. https://doi.org/10.1016/0022-0981(79)90136-9.

Carlos, C., Emese, P., \& Dimitrios, B. (2013). Trends in European tourism planning and organization. Trends in European Tourism Planning and Organisation. https://doi.org/10.1108/jtf-12-2014-0007

Carnegie, M. (2014). Sailing-trading livelihoods in Southeastern Indonesia: Adapting to change. Asian Journal of Social Science, 41, 543-579. https://doi.org/10.1163/15685314-12341330

Cingano, F. (2014). Trends in Income Inequality and its Impact on Economic Growth. OECD Social, Employment, and Migration Working Papers. OECD Publishing, http://dx.doi.org/10.1787/5jxrjncwxv6j-en

Clifton, J, Unsworth, R., \& Smith, D. (2010). Marine research and conservation in the coral triangle: the Wakatobi national park. Environmental Science, Engineering and Technological Series. Nova Science Publishers, Inc.; UK ed. ISBN: 978-1-61668-473-0.

Clifton, Julian. (2013). Refocusing conservation through a cultural lens: Improving governance in the Wakatobi National Park, Indonesia. Marine Policy, 41, 80-86. https://doi.org/10.1016/j.marpol.2012.12.015

Cole, S. (2012). A political ecology of water equity and tourism: A case study from Bali. Annals of Tourism Research, 39(2), 1221-1241. https://doi.org/10.1016/j.annals.2012.01.003

Cole, S. (2014). Tourism and water: from stakeholders to rights holders, and what tourism businesses need to do. Journal of Sustainable Tourism, 22(1), 89106. https://doi.org/10.1080/09669582.2013.776062

Cole, S. (2017). Water worries: An intersectional feminist political ecology of tourism and water in Labuan Bajo. Indonesia, Annals of Tourism Research, 67, 14-24. https://doi.org/10.1016/j.annals.2017.07.018

Cole, S., \& Browne, M. (2015). Tourism and Water Inequity in Bali: A Social-Ecological Systems Analysis. Human Ecology, 43(3), 439-450. https://doi.org/10.1007/s10745-015-9739-z

Cole, S., \& Morgan, N. (2010). Tourism and inequality: Problems and prospects. Annals of Tourism Research, 38(3), 1193-1195.

Croes, R. (2014). The role of tourism in poverty reduction: An empirical assessment. Tourism Economics, 20(2), 207-226. https://doi.org/10.5367/te.2013.0275

Deac, L.A., Gozner, M. \& Sambou A. (2019). Ethnographic museums in the rural areas of Crișana region, Romania - keepers of local heritage, tradition and lifestyle. GeoJournal of Tourism and Geosites, 27(4), 1251-1260. http://doi.10.30892/gtg.27411-430

Dezsi, S., Rusu, R., Ilies, M., Ilies, G., Badarau, A.S., \& Rosian, G. (2014). The role of rural tourism in the social and economic revitalisation of Lapus land (Maramures County, Romania), in Geoconference on Ecology, Economics, Education and Legislation, VOL II, Book Series: International Multidisciplinary Scientific GeoConference-SGEM- Proceedings Paper, 783-790. https://www.researchgate.net/publication/293110624

De Alessi, M. (2014). Archipelago of Gear: The Political Economy of Fisheries Management and Private Sustainable Fisheries Initiatives in Indonesia. Asia and the Pacific Policy Studies, 1(3), 576-589. https://doi.org/10.1002/app5.40

De Vita, G., \& Kyaw, K.S. (2017). Tourism Specialization, Absorptive Capacity, and Economic Growth. Journal of Travel Research, 56(4), 423-435. https://doi.org/10.1177/0047287516650042

Dilwan, M.Al., \& Astina, I.K. (2019). Community Based Wakatobi Tourism Management Strategies. In International Conference on Social Knowledge Sciences and Education (ICSKSE 2018), 320. https://doi.org/10.2991/icskse-18.2019.9

Dredge, D. (2006). Networks, conflict and collaborative communities. Journal of Sustainable Tourism, 14(6), 562-581. https://doi.org/10.2167/jost567.0

Elliott, G., Mitchell, B., Wiltshire, B., Manan, A., \& Wismer, S. (2001). Community participation in marine protected area management Wakatobi National Park, Sulawesi, Indonesia. Coastal Management, 29(4), 295-316. https://doi.org/10.1080/089207501750475118

Febryano, I.G. (2015). Aktor Dan Relasi Kekuasaan Dalam Pengelolaan Mangrove Di Kabupaten Pesawaran, Provinsi Lampung, Indonesia. Jurnal Analisis Kebijakan Kehutanan, 12(2), 123-138. https://doi.org/10.20886/jakk.2015.12.2.125-142

Firmansyah, F., Mustofa, A., Estradivari, E., Damora, A., Handayani, C., Ahmadia, G., Harris, J., Amkietela, A., Teule, K., Sugiyanta, S., Santiadji, V., Wijonarno, A., \& Yusuf, A. (2017). Relationship Between the Wakatobi National Park Zonation System and Dynamics of Coral Reef Ecosystem Condition, 1(2), 147-156.

Fredman, P., Wall-Reinius, S., \& Grundén, A. (2012). The Nature of Nature in Nature-based Tourism. Scandinavian Journal of Hospitality and Tourism, 12(4), 289-309. https://doi.org/10.1080/15022250.2012.752893

Fredman, P., \& Wikström, D. (2018). Income elasticity of demand for tourism at Fulufjället National Park. Tourism Economics, 24(1), 51-63. https://doi.org/10.1177/1354816617724012

Hewlett, D., \& Edwards, J. (2013). Beyond Prescription: Community Engagement in the Planning and Management of National Parks as Tourist Destinations. Tourism Planning and Development, 10(1), 45-63. https://doi.org/10.1080/21568316.2012.723041

Herman, G.V., Wendt, A.J., Dumbravă, R., \& Gozner, M. (2019). The role and importance of promotion centers in creating the image of tourist destination: Romania. Geographia Polonica, 92(4), 443-454. https://doi.org/10.7163/GPol.0158

Ilies A., Hurley P.D., Ilies D.C., Baias S. (2017). Tourist animation -a chance adding value to traditional heritage: case study in the Land of Maramures (Romania), Revista de Etnografie si Folclor, New Series 1-2, 131-151.

Ilieș, D.C., Caciora, T., Herman, G.V., Ilieș, A., Ropa, M., \& Baias, Ș. (2020). Geohazards affecting cultural heritage monuments. A complex case study from Romania. GeoJournal of Tourism and Geosites, 31(3), 1103-1112. https://doi.org/10.30892/gtg.31323-546

Jaafar, M., Rasoolimanesh, S.M., \& Lonik, K.A.T. (2015). Tourism growth and entrepreneurship: Empirical analysis of development of rural highlands. Tourism Management Perspectives, 14, 17-24. https://doi.org/10.1016/j.tmp.2015.02.001

Jamal, T., \& Camargo, B.A. (2018). Tourism governance and policy: Whither justice? Tourism Management Perspectives, 25, 205-208. https://doi.org/10.1016/j.tmp.2017.11.009

Joppe, M. (2018). Tourism policy and governance: Quo vadis? Tourism Management Perspectives, 25, 201-204. https://doi.org/10.1016/j.tmp.2017.11.011

Junaid, I., Salam, N., \& Salim, M.A. (2019). Developing homestay to support community-based tourism. Masyarakat, Kebudayaan Dan Politik, 32(4), 390398. http://dx.doi.org/10.20473/mkp.V32I42019.390-398

Kaltenborn, B.P., Nyahongo, J.W., \& Kideghesho, J.R. (2011). The attitudes of tourists towards the environmental, social and managerial attributes of Serengeti National Park, Tanzania. Tropical Conservation Science, 4(2), 132-148. https://doi.org/10.1177/194008291100400204

Karanth, K.K., Defries, R., Srivatsha, A., \& Sankaraman, V. (2012). Wildlife tourists in India's emerging economy: Potential for a conservation constituency? ORYX, 46(3), 382-390. https://doi.org/10.1017/S003060531100086X 
Khac, A. Do. (2018). The Political Sea: Conservation Policies, State Power, and Symbolic Violence The Case of the Bajau in the Wakatobi Marine National Park. Explorations: A Graduate Student Journal of Southeast Asian Studies, 14, 37-50.

Kodir, A. (2018). Tourism and development: Land acquisition, achievement of investment and cultural change (case study tourism industry development in Batu City, Indonesia). Geojournal of Tourism and Geosites, 1(21), 253-265. https://doi.org/10.30892/gtg.21120-285

Kodir, A. (2019). Political Ecology of a Spring: People's Resistance to the Construction of a Hotel. Journal of Asian Sociology, 48(2), 179-198. https://doi.org/10.21588/jas/2019.48.2.002

Kodir, A., Tanjung, A., Astina, I.K., Nurwan, M.A., \& Nusantara, A.G. (2020). The Dinamics Of Access On Tourism Development In Labuan Bajo, Indonesia. GeoJournal of Tourism and Geosites, 29(2), 662-671. https://doi.org/10.30892/gtg.29213-488

Kodir, A., Tanjung, A., Sumarmi, S., Ahmad, R., \& Simanjuntak, T. (2019). Tourism Governance in Komodo National Park, Indonesia: Blessing or Curse? Geo Journal of Tourism and Geosites, 27(4), 1401-1417. https://doi.org/10.30892/gtg.27424-443

Lee, D., Hampton, M., \& Jeyacheya, J. (2015). The political economy of precarious work in the tourism industry in small island developing states. Review of International Political Economy, 22(1), 194-223. https://doi.org/10.1080/09692290.2014.887590

Martin, T.E., Kelly, D.J., Keogh, N.T., Heriyadi, D., Singer, H.A., \& Blackbu, G.A. (2012). The avifauna of Lambusango Forest Reserve, Buton Island, southeast Sulawesi, with additional sightings from southern Buton. Forktail.

Masoed, M. (1994). Ekonomi-politik internasional dan pembangunan. Pustaka Pelajar.

Mayer, M., Müller, M., Woltering, M., Arnegger, J., \& Job, H. (2010). The economic impact of tourism in six German national parks. Landscape and Urban Planning, 97(2), 73-82. https://doi.org/10.1016/j.landurbplan.2010.04.013

Medina-Muñoz, D.R., Medina-Muñoz, R.D., \& Gutiérrez-Pérez, F.J. (2016). The impacts of tourism on poverty alleviation: an integrated research framework. Journal of Sustainable Tourism, 24(2), 1-29. https://doi.org/10.1080/09669582.2015.1049611

Nugroho, I., Negara, P.D., \& Yuniar, H.R. (2018). The Planning And The Development Of The Ecotourism And Tourism Village In Indonesia: A Policy Review. Journal of Socioeconomics and Development, 1(1), 43-51. https://doi.org/10.31328/jsed.v1i1.532

Nunkoo, R. (2017). Governance and sustainable tourism: What is the role of trust, power and social capital? Journal of Destination Marketing and Management, 6(4), 277-285. https://doi.org/10.1016/j.jdmm.2017.10.003

Ohlan, R. (2017). The relationship between tourism, financial development and economic growth in India. Future Business Journal, 3(1), 9-22. http://dx.doi.org/10.1016/j.fbj.2017.01.003

Owners, P., Delacy, T., \& Jiang, M. (2019). Transforming a tourism destination into a green economy: A policy analysis of Wakatobi Islands, Indonesia. IOP Conference Series: Earth and Environmental Science, 363(1). https://doi.org/10.1088/1755-1315/363/1/012004

Priyatna, F.N., Kinseng, R.A., \& Satria, A. (2015). Akses Dan Strategi Aktor-Aktor Dalam Pemanfaatan Sumber Daya Waduk Djuanda. Jurnal Sosial Ekonomi Kelautan Dan Perikanan, 8(1), 1-9. http://dx.doi.org/10.15578/jsekp.v8i1.1190

Puhakka, R., \& Saarinen, J. (2013). New Role of Tourism in National Park Planning in Finland. Journal of Environment and Development, 22(4), 411-434. https://doi.org/10.1177/1070496513502966

Rangan, H. (1997). Property vs. Control: The State and Forest Management in the Indian Himalaya. Development and Change, 28(1), 71-94. https://doi.org/10.1111/1467-7660.00035

Ribot, J.C., \& Peluso, N.L. (2009). A Theory of Access. Rural Sociology. https://doi.org/10.1111/j.1549-0831.2003.tb00133.x.

Rubinson, R. (2005). A Theory of Acces to Justice. Journal of the Legal Proffesion, 29, 89-156.

Scheyvens, R. (2014). Tourism and poverty reduction. Tourism and Development: Concepts and Issues, 2nd Edition, https://doi.org/10.21832/9781845414740-006.

Scott, N., \& Marzano, G. (2015). Governance of tourism in OECD countries. Tourism Recreation Research, 40(2), 1-13. https://doi.org/ $10.1080 / 02508281.2015 .1041746$

Seligson, M.A., \& Kuznets, S. (2019). Economic Growth and Income Inequality. In The Gap between Rich and Poor, https://doi.org/10.4324/9780429311208-4.

Shomanova, Z.K., Safarov, R.Z., Tleulesov, A.K., Nosenko, Yu.G., Zhumakanova, A.S., \& Larichkin, V.V. (2017). Study of composition of waste from metallurgy production aimed in use them as active phases of catalysts for hydrocarbon raw materials refining. News of the National Academy of Sciences of the Republic of Kazakhstan, Series of Geology and Technical Sciences, 2017, 6(426), c. 195-200.

Sharma, C., \& Rajagopalan, R. (2013). Marine protected areas: securing tenure rights of fishing communities? Land Tenure Journal, https://doi.org/10.1111/j.1523-1739.2010.01523.x

Shultis, J.D., \& Way, P.A. (2006). Changing conceptions of protected areas and conservation: Linking conservation, ecological integrity and tourism management. Journal of Sustainable Tourism, 14(3), 237-223. https://doi.org/10.1080/09669580608669056

Sikor, T., \& Lund, C. (2009). Access and Property: A Question of Power and Authority. Development and Change, 40(1), 1-22. https://doi.org/10.1111/j.1467-7660.2009.01503.x

Simonin, P.W. (2015). From sea to spirit: Resilience conceptions in coastal communities of Kaledupa, Indonesia. Resilience, 3(3), 199-206. https://doi.org/10.1080/21693293.2015.1072312

Sinha, A., Driha, O., \& Balsalobre-Lorente, D. (2020). Tourism and inequality in per capita water availability: is the linkage sustainable? Environmental Science and Pollution Research, 27(9), 10129-10134. https://doi.org/10.1007/s11356-020-07955-6

Sinha, C. (2012). Tourism in Wakatobi: Stakeholders' Perspectives on Participation. June.

Sopari, H., Oka, N.P., \& Salman, D. (2014). Model Kolaborasi Perencanaan Antara Balai Taman Nasional Wakatobi Dan Pemerintah Kabupaten Wakatobi Dalam Pengelolaan Sumber Daya Alam Hayati Secara Lestari. Journal Sains \& Teknologi, 14(2), 189-198. https://doi.org/10.29122/jsti.v14i1

Spenceley, A., \& Meyer, D. (2012). Tourism and poverty reduction: Theory and practice in less economically developed countries. Journal of Sustainable Tourism, 20(3), 297-317. https://doi.org/10.1080/09669582.2012.668909

Stacey, N., Acciaioli, G., Clifton, J., \& Steenbergen, D.J. (2017). Impacts of Marine Protected Areas on Livelihoods and Food Security of the Bajau as an Indigenous Migratory People in Maritime Southeast Asia. Marine Protected Areas: Interactions with Fishery Livelihoods and Food Security.

Suleimenov, I., Egemberdieva, Z., Bakirov, A., Baipakbayeva, S., Kopishev, E., \& Mun, G. (2020). Efficiency Problem of renewable energetics systems in the context of a «smart house» concept. E3S Web of Conferences, 164.

Syam, M., Aprillia, T., \& Maulana, I. (2019). Ecotourism: An alternative of socio-ecological crisis? IOP Conference Series: Earth and Environmental Science, 241(1). https://doi.org/10.1146/annurev-environ-101718-033046

Tam, C.L. (2019). Branding wakatobi: Marine development and legitimation by science. Ecology and Society, vol. 24, no. 3. https://doi.org/10.5751/ES-11095-240323

Tătar, C.F., Herman, G.V., \& Gozner, M. (2018). Tourist guides' contribution to sustainability in Romania. GeoJournal of Tourism and Geosites, 21(1), 282287. https://doi.org/10.30892/gtg.21122-287

Ullah, Z., Badshah, S.I., \& Shaheen, M. (2017). Strategic Analysis of Selected Case Studies for Their. Journal of Business and Tourism, $221-233$.

Valente, F., Dredge, D., \& Lohmann, G. (2015). Leadership and governance in regional tourism. Journal of Destination Marketing and Management, 4(2), 127-136. https://doi.org/10.1016/j.jdmm.2015.03.005

Vanegas, M., Gartner, W., \& Senauer, B. (2015). Tourism and poverty reduction: An economic sector analysis for Costa Rica and Nicaragua. Tourism Economics, 21(1), 159-182. https://doi.org/10.5367/te.2014.0442

Von Heland, F., \& Clifton, J. (2015). Whose Threat Counts? Conservation Narratives in the Wakatobi National Park, Indonesia. Conservation and Society, 13(2), 154-165. https://doi.org/10.4103/0972-4923.164194

Wan, Y.K.P., \& Bramwell, B. (2015). Political economy and the emergence of a hybrid mode of governance of tourism planning. Tourism Management, 50, 316-327. https://doi.org/10.1016/j.tourman.2015.03.010

Wahyuningtyas, N., Tanjung, A., Kodir, A., Wijanarko, H. \& (2020). Management of Tourism Areas Based on Disaster Mitigation (Case Study of Senggigi Beach), IOP Conference Series, Earth and Environmental Science, 412 (1), 012015. https://doi.org/10.1088/1755-1315/412/1/012015

Yeh, C.M. (2018). Does board governance matter for foreign institutional investors to invest in listed tourism firms? Tourism Management, 68, 66-78. https://doi.org/10.1016/j.tourman.2018.03.001 